\title{
AN OVERVIEW OF NURSING EDUCATION IN NEPAL
}

\author{
Pragya Shrestha, ${ }^{1}$ Kamala Paudel, ${ }^{1}$ Astha Sharma Pokharel ${ }^{1}$
}

\begin{abstract}
Nursing is the most valued public service leaning profession. The quality of nursing education and future of nurse remains a growing concern with international standards in Nepal. The perspective of nursing educationists reveals the scholastic, academic and practical sight to understanding of advancement in the nursing education. Nepal has been running nursing education in the Government as well as in private sectors throughout the country. Nursing education focused with changes as center of attention at the certificate level to highlight prospective functions in the public health and at the bachelor level to focus on advancement of leadership skills.

There are many problems in the existing nursing education which need to be addressed by the concerned authority for quality nursing education in the country. Nepal Nursing Council Act has made a mandatory provision that prior to granting approval to establish and operate a nursing educational institution; the concerned body shall consult the council for establishing and operating any nursing educational institution. The continuous and routine supervision and monitoring is needed to be made from the university as well as from the Nepal Nursing Council, Ministry of Education.
\end{abstract}

KEYWORDS Nursing Education, Nepal

1. Universal College of Nursing Sciences, UCMS, Bhairahawa, Nepal

DOI: http//doi.org/10.3126/jucms.v8i1.29843

\author{
For Correspondence \\ Ms. Pragya Shrestha \\ Universal College of Nursing Sciences \\ UCMS \\ Bhairahawa, Nepal \\ Email: pragyashrsth80@gmail.com
}




\section{INTRODUCTION}

The formal training of nursing in Nepal began with the establishment of School of Nursing in Surendra Bhawan in 1st June 1956 AD (2013 BS) with support of WHO. ${ }^{1}$ There were fifteen students in first intake of nursing school. Among them only eleven students succeeded nursing course. After three years, that school was transferred from Surendra Bhawan to Chhetrapati again a few years later the school was transferred to Bir Hospital at Mahabuddha named as HMG School of Nursing, Mahabauddha. Another school of nursing was established under the UMN in Nepal in 1959 AD (2016 BS), NirbhawanSanepa. ${ }^{2}$

Nursing education in Nepal entered into the main stream of education only when it came under the Institute of Medicine, Tribhuvan University in 1972 AD (2029 BS). It was recognized as the part of university program. At the same time, HMG School of Nursing was named as Mahabauddha Nursing Campus. Finally it was named as Maharajgunj Nursing Campus in 1986 AD (2042 BS). In 1989 AD (2046 BS) nursing program was restarted in Bir Hospital with the affiliation to Tribhuwan University (TU).

Before becoming nursing education under IOM, final examinations used to held by NNC but IOM took over all the regulatory functions of NNC since its establishment in 1972 AD (2029 BS). It not only conducted final examination and issuing the certificates to students but also worked on standardization of nursing curriculum. The change reinforced the placement system; SLC should be passed compulsorily forthe admission in Nursing. The program was changed from annual system to semester to match the other programs of university. But, again it was changed in annual system in 1980. The nursing program was $3 \frac{1}{2}$ years duration before 1972 but it was reduced in 3 years later. In 1973 (2030 BS), Princes Prekshya joined nursing training during the regime of King Birendra which brought great change in nursing. ${ }^{3}$

Great changes occurred in 1986 AD (2042 BS); all certificate nursing programs enrolled $10 \%$ male students in their programs. But after four batches of intake this policy was stopped. Again new policy has been broughtwith the increasement of $15 \%$ male students in nursing since 2018 AD (2075 BS). As per the Government policy PCL nursing programs has been phased out from Maharajgunj Nursing Campus from the year $2015 .^{4}$

The following nursing programs are existence in $\mathrm{Nepal}^{5-8}$

\section{Auxiliary Nurse Midwifery (ANM)}

The courses for ANM training started in the late 1960s with goal of organizing a nursing workforce to work in rural health posts providing Maternal and Child Health Services in Nepal. Near the beginning 1980s, only just five ANM programs were under Tribhuvan University. The first ANM School was opened at Bharatpur in 1962 with the help of USA. Later, another ANM extension campus opened in Biratnagar in 1966; likewise in Nepalgunj in 1969, in Tansen in 1973 and in Chhetrapati in 1975. Gradually, the number increased to 50 after taken over by CTEVT in early 1990s which all runs privately nowadays.

\section{Proficiency Certificate Level Nursing (PCL)}

TU ANM campuses were eventually upgraded to PCL. Altogether there were seven PCL nursing campuses including Lalitpur Nursing Campus, Sanepa. The number started to increase in the 1990's with thought of providing more staff nurses for the center, district and other Government hospitals. Authority to produce other PCL nursing program was given to Council of Technical Education and Vocational Training (CTEVT) in 1999 AD. Since 2000 AD, several private PCL nursing campuses were established under CTEVT.

Similarly, PCL nursing program are run by different universities and institutes, they are: Tribhuvan University (TU), Kathmandu University (KU), B.P. Koirala Institute of Health Sciences (BPKIHS), Patan Academy of Health Sciences (PAHS) and National Academy Of Medical Sciences (NAMS).

\section{Institutions for Starting PCL Nursing Program}

\begin{tabular}{lll}
\hline Name of institution & Year of initiation & Duration \\
\hline Institute of Medicine, Tribhuvan University & $1956 \mathrm{AD}$ & 3 years \\
$\begin{array}{l}\text { Council for Technical Education \& Vocational } \\
\text { Training (CTEVT) }\end{array}$ & $2000 \mathrm{AD}$ & 3 Years \\
Kathmandu University & $1998 \mathrm{AD}$ & \\
B.P. Koirala Institute of Health Sciences, Dharan & $1999 \mathrm{AD}$ & 3 Years \\
National Academy of Medical Sciences & $1989 \mathrm{AD}$ & 3 Years \\
Patan Academy of Health Sciences & $2016 \mathrm{AD}$ & 3 Years \\
Karnali Academy of Health Sciences & $2013 \mathrm{AD}$ & 3 years \\
\hline
\end{tabular}

\section{Bachelor in Nursing Program}

Mahabuddha Nursing campus (presently Maharajgunj Nursing Campus) started post basic bachelor level programme in 1978 AD (2035 BS). In 1977 (2033 BS) Bachelor of Nursing in midwifery was introduced, further in community (1980), adult (1983) and pediatric (1984) were gradually introduced. Now, the three tracts (Hospital, Community and Psychiatric Programs) are running well in nursing campus Maharajgunj. 


\section{Bachelor of Nursing (BNS)}

In $2013 \mathrm{AD}$ a big change was made in Bachelor in nursing program with the addition of basic science courses, English and computer. The duration of course was made three years from two years.

There are numerous nursing colleges, offering either BNS or B Sc. Nursing or both under TU, BPKIHS, PU, KU, PAHS or NAMS either as constituent campus or affiliated campuses.

Institutions for starting Bachelor of Nursing (BNS) program

\begin{tabular}{|c|c|c|}
\hline Name of institution & $\begin{array}{l}\text { Year of } \\
\text { initiation }\end{array}$ & Major subjects \\
\hline TribhuwanUniversity,Institute of Medicine & $1976 \mathrm{AD}$ & $\begin{array}{l}\text { Community, psychiatric, child, } \\
\text { adult, midwifery }\end{array}$ \\
\hline Kathmandu University & $2004 \mathrm{AD}$ & Not existing \\
\hline $\begin{array}{l}\text { B.P. Koirala Institute of Health } \\
\text { Sciences, Dharan }\end{array}$ & $2012 \mathrm{AD}$ & Present not existing \\
\hline Purbanchal University & $2005 \mathrm{AD}$ & Community, midwifery, adult \\
\hline Pokhara University & $2018 \mathrm{AD}$ & Oncology nursing \\
\hline National Academy of Medical Sciences & $2005 \mathrm{AD}$ & Critical care nursing, midwifery \\
\hline Patan Academy of Health Sciences & $2016 \mathrm{AD}$ & Community, psychiatric and adul \\
\hline Karnali Academy of Health Sciences & & Midwifery Nursing \\
\hline
\end{tabular}

\section{Basic B. Sc. Nursing program}

B.Sc. Nursing program was started in BPKIHS, Dharan in 1996 AD (2053 BS) at first. Gradually this program was started by different universities and institutions. The criteria for enrollment of students are those candidates who have passed $10+2$ in science, biology as major subject scoring minimum $50 \%$. Duration of course is 4 years.

Institutions for starting Bachelor of Sciences in Nursing program

\begin{tabular}{ll}
\hline Name of institution & Year of initiation \\
\hline B.P. Koirala Institute of Health Sciences, Dharan & $1996 \mathrm{AD}$ \\
Kathmandu University & $2004 \mathrm{AD}$ \\
Institute of Medicine, Tribhuvan University & $2005 \mathrm{AD}$ \\
Purbanchal University & $2005 \mathrm{AD}$ \\
Pokhara University & $2012 \mathrm{AD}$ \\
Patan Academy of Health Sciences & $2016 \mathrm{AD}$ \\
\hline
\end{tabular}

\section{Master of Nursing Program and Ph.D Nursing}

Master of Nursing Program was started in Maharajgunj Nursing Campus in 1995 AD at first. The major focus was given to Women Health and Development as per the country's need. Gradually master in nursing programme extended to different specialties. The specialities are Adult Nursing, Child Health Nursing and Psychiatric Nursing. Nursing in Ph.D. was started in 2012.

\begin{tabular}{|c|c|c|c|}
\hline Name of institution & $\begin{array}{l}\text { Year of } \\
\text { initiation }\end{array}$ & Duration & Specialties \\
\hline $\begin{array}{l}\text { Institute of Medicine, Tribhuvan } \\
\text { University }\end{array}$ & $1995 \mathrm{AD}$ & 2 years & $\begin{array}{l}\text { WHD, Adult, Child, } \\
\text { Psychiatric }\end{array}$ \\
\hline Kathmandu University & $2016 \mathrm{AD}$ & 2 years & $\begin{array}{l}\text { Medical-Surgical, Pediatric, } \\
\text { Psychiatric }\end{array}$ \\
\hline $\begin{array}{l}\text { B.P. Koirala Institute of Health } \\
\text { Sciences, Dharan }\end{array}$ & $2008 \mathrm{AD}$ & $\begin{array}{l}3 \text { years till } 2015 \\
\text { then } 2 \text { years }\end{array}$ & $\begin{array}{l}\text { Community, Psychiatric, } \\
\text { Pediatric, Adult, Midwifery }\end{array}$ \\
\hline $\begin{array}{l}\text { National Academy of Health } \\
\text { Sciences }\end{array}$ & $2015 \mathrm{AD}$ & 2 years & Midwifery, Pediatric \\
\hline $\begin{array}{l}\text { Patan Academy of Health } \\
\text { Sciences }\end{array}$ & $2016 \mathrm{AD}$ & 2 years & $\begin{array}{l}\text { Community, psychiatric, } \\
\text { women health development, }\end{array}$ \\
\hline
\end{tabular}

\section{Trends in Nursing Education Program}

Trends mean movement in particular direction according to time, environment and situation. Nursing is a dynamic profession and thereby gives rises to trends. There are some of the current trends in nursing education. ${ }^{6}$

\section{Curriculum changes}

Flexibility in curriculum designs to facilitate diversity of education opportunity has involved. It is often competent based focused on outcome and emphasis student participation and responsibility for learning.

\section{Innovations in teaching and learning}

A lot of innovations are taking place in the areas of teaching and learning. These innovations lead to intellectual development, personal development and career development.

\section{Educational quality Assurance}

Nursing education is flourishing in an unprecedented manner; naturally this will lead to dilution in the quality of nursing education in the absence of proper quality of nursing education in the absence of proper quality control measures. It is high time to prepare a quality index of nursing institutions all over the country by categorizing them into different grades based on infrastructure and faculty profile.

\section{More reliance on technology}

Technology exerts greater influence on nursing education as a tool for teaching and learning. Judicious use of educational psychology in the development and practice of educational technology has increased its user friendly nature considerably.

\section{Emphasis on high- tech- high touch approach}

High- tech- high touch approach in nursing care was devised to preserve the human component of nursing care without undermining the advantages in technological advancement in 
the field of patient care. Present day nursing education is preparing students to maintain the human element of nursing while caring the patients with the help of sophisticated gadgets.

\section{Preparation of global nurses}

Globalization will continue to impact in the economic, political and social aspects of life. Nursing education is all set to reap benefits created by globalization and liberalization by way of preparing global nurses. Many institutions are preparing students with a global perspective through providing learning experiences to enrich students' knowledge in English along with the attainment of other objectives.

\section{Transnational acceptance}

Nursing educational programs in one nation is widely accepted by all nations. In fact, this transnational acceptance is the main reason for the development of nursing education in the countries.

\section{Promising career}

As the medical and allied fields grow, nursing education is also offering new specialties to meet the needs of the community.

\section{Increased opportunities for higher studies}

Different from the past many institutions are offering programs such as post certificate B. Sc. Nursing, M. Sc. Nursing, M. Phil and Ph. D. An eligible candidate can easily pursue higher education without much time lag.

\section{Diminishing Government role}

Shortage of funds coupled with certain policy decisions has prevented the government from investing further in the field of nursing education. Now, the private sector is playing a dominant role for the development of nursing education.

\section{Uniformity and standardization}

Various universities and nursing boards are conducting nursing programs in a different manner. A uniformity and standardization are maintained in line with the guidelines given by the Nepal Nursing council.

\section{Impact of globalization}

The status of nursing is shifted from a caring profession to a rewarding profession as a result of impact of globalization. Very few students are trying to inculcate the traditional values of nursing profession during their student period. Majority consider nursing education only as a means for securing a rewarding career. Nursing education sector is trying hard to cope with this worrisome impact of globalization.

\section{Enhances student status}

In the past, students joining for nursing educational program were viewed as student nurses rather than nursing students. Increased career opportunities offered by the nursing as well as the tremendous increase in the number of nursing institutions prompted society and other health care professions to consider nursing students as nursing students.

\section{Issues in nursing education}

Issues are different opinions of a particular subject. Issues are mean problem or difficulties. Issues are a point or matter of discussion, debate or dispute or a matter of public concern. There are major issues in nursing education in Nepal. ${ }^{6,79,10}$

\section{Nursing shortage}

National problem which is growing. In spite of high production there is nursing shortage in the clinical areas. The standard nurse patient ratios are seldom met. There is critical shortage in specialty areas of nursing. Reasons for this shortage are lack of conducive work environment, appropriate recruitment process and retention process ageing work, lack of compensation and lack of nursing faculty.

\section{Patient satisfaction}

Patient satisfaction and patient compliance is the main aim of the profession. This can be achieved through good customer service i.e. satisfactory patient care. Health care is a form of business that can flourish through the satisfaction of the clients meeting their health care demands. Patient Bills of right is to be kept in consideration while providing service to the clients. It should be respected by all the nursing professionals.

\section{Trans-cultural nursing}

Nursing has become a melting pot. Trans-cultural nursing is a method that was introduced to the health care field by Madeleine Leininger, RN in 1950s. According to her, it is very important for nurses to really find out about people's traditions, life ways and beliefs about health care, so they can honor them and combine them with professional care. So nurses are challenged to be more culturally aware and identify the cultural sensitivity of each individual.

\section{Evidence based practice}

The goal of the health facilities is to achieve cost-effective, high quality patient care based on scientific inquiry. Nurses 
need to understand research process involved. Nursing care should not be based on opinions, past practices, but on the results of scientific research. Based on the research findings clinical journals are published that helps in the formulation of the practice guidelines.

\section{Information age}

Consumers today are more computer savvy regarding healthcare. There is more information in the internet regarding health care and health facilities. Consumers could possibly be more informed than health care worker. This creates a challenge to the nursing to be more informed and dealing with the public.

\section{Globalization}

Healthcare has become a global issue. People are mobile they keep moving from one region to the other. Along with them diseases can travels from one part to the other. Nurses need to have an understanding of the issues pertaining to global health.

\section{Legal issues in nursing}

There are various legal issues in the daily nursing practice while caring of the clients nurse practice act, standards of professional practice, advanced directives, licensure, public health laws, physician-assisted suicide are some of the legal acts that guide and monitor the nursing practice. Some of the common civil and common law issues in Nursing Practice are intentional tort, unintentional tort, negligence, malpractice, consent, informed consent, malpractice insurance, abandonment and assignment Issues.

\section{Terrorism, bioterrorism and disaster nursing}

Nurses need to be aware to the health consequences of terrorism and use of biological agents. Early recognition and management of a biological attack are largely dependent on the clinical expertise of frontline health care personnel. Nurses are recognized as an integral part of this team. Schools of nursing should integrate bioterrorism education into their curricula to address this growing frontier of health care management. Disasters are one of the main concerns as well. The preparedness as well as the response of disaster is of major concern in the nursing education.

\section{Major challenges}

There are major challenges in nursing education and relevant practices in Nepal. The challenges are faced by nursing students while applying learnt education to the nursing practice. $^{7}$
1. Challenges are there while implementing appropriate feedback systems to deliver quality and efficient health services,

2. Challenges do persist in arrangement to be made in the hospitals to response to emergency health needs. More efforts are needed to retrofit hospitals and health institutions. Capacity building needs to be done for emergency response to measures to take emergency response not only for natural disaster but to develop adequate response measures to take emergency situations like bird flu and diseases out breaks.

3. The initiative to control diarrhea, respiratory diseases, malaria, kala-azar, encephalities, filariasis, dengue, TB, $\mathrm{HIV}$ and vaccine preventable diseases needs to be more effective to achieve MDG targets.

4. Control the cross border transmission of communicable diseases (human and animal) is a challenge because of the open border.

5. Foreseen challenges are there to enable local health institutions to implement suitable social health insurance and provide an opportunity conducive for equitable quality health services, education and information for all citizens.

6. State investment in the health sector till needs to be at par to the population growth.

7. Geographical imbalance in the achieving health indicators needs to be addressed urgently remain to effectively enforce health- related acts, rules, policies, strategies and action plan in an appropriate, integrated and efficient manner. It is necessary that the local government be empowered and makes publicresponsive while fostering people's participation in the health programs at the rural areas.

\section{REFERENCES}

1. Adhikari R. The "Dream-Trap": Brokering "Study Abroad" and Nurse Migration from Nepal to the UK. European Bulletin of Himalayn Research. 2010;35-36: 122-138.

2. Prakash S, Yadav P, Yadav K. Perspectives of developing nursing education in Nepal. Nurse Care Open Acces J. 2018;5(4):214-20.

3. Sigdel R. Nursing education in Nepal: Historical perspective. Health Prospect. 2011;10:89-90.

4. Shahi M, Agrawal J. Feasibility study on upgrading the bachelor nursing curriculum in Nepal. Social Sciences. 2013;50:50. 
5. Mahler H. Present Status of WHO's Initiative," Health For All by the Year 2000". Annual Review of Public Health. 1988 May; 9(1):71-97.

6. Rai L. Nursing concepts theories and principles. 4th ed. Kathmandu:Akshav; 2019. 17-26

7. Singh I. Essentials of education. 9th ed. Kathmandu: Mr. J.B. Singh; 2019. 24-35

8. Paudel K. Report on status of nurses in Nepal. 2010.

9. Leininger M. Transcultural nursing research to transform nursing education and practice: 40 years. Image: The Journal of Nursing Scholarship. 1997 Dec;29(4):341-8.

10. Steed CJ, Howe LA, Pruitt RH, Sherrill WW. Integrating bioterrorism education into nursing school curricula. Journal of Nursing Education. 2004 Aug 1;43(8):362-7. 